\title{
Determinants of investor behavior in SET50 index futures and options markets: Evidence from Thailand Futures Exchange
}

\author{
Woradee Jongadsayakul \\ Department of Economics, Kasetsart University, \\ Thailand \\ fecowdj@ku.ac.th
}

\begin{abstract}
This study provides a new empirical evidence to demonstrate the factors influencing investors' behavior at SET50 index futures and options markets via two types of simultaneous equation estimation, Two Stage Least Squares (2SLS) and Three Stage Least Squares (3SLS). Both 2SLS and 3SLS estimation results show a bilateral causality between stock market volatility and derivatives market activities. Between futures trading and options trading, there is a bilateral causality in 3SLS model, but there is a unidirectional causality from futures market activity to options market activity in 2SLS model. Turnover ratio has a positive impact on stock market volatility, but its relationship with speculative behavior relative to hedging behavior in SET50 index futures is negative in both methods. Only 3SLS model shows a negative impact of turnover ratio on the relative importance of speculative activity at SET50 index options market. Moreover, the proportion of foreign investors shows a positive relationship with speculative investor behavior at SET50 index futures market. There is an increase in SET50 index options trading by foreign and institutional investors for speculation, relative to hedging. Speculative trading is mostly related to put options, while hedging trading is mostly related to call options.
\end{abstract}

Keywords: index futures, index options, investor behavior, Thailand Futures Exchange.

JEL Classification: G12, G23, G32

\section{INTRODUCTION}

After complete merger of the Agricultural Futures Exchange of Thailand into Thailand Futures Exchange (TFEX) in 2016 to improve operational efficiency and reduce transaction costs for investors' benefits, TFEX is now the only organized derivative exchange market in Thailand. It hosts all derivative trading such as index futures and options, stock futures, gold futures, interest rate futures, currency futures, and rubber futures. The drastic growth of TFEX is partly evidenced by their improved world rankings from its 2011 ranking of 45th to ranking of 26th in 2017 in the Futures Industry Association's global list of the 
top derivatives exchanges. Its trading volume increased from 10.027 million contracts in 2011 to 78.991 million contracts in 2017.

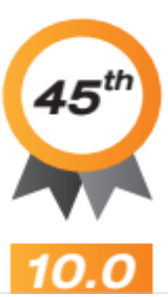

2011

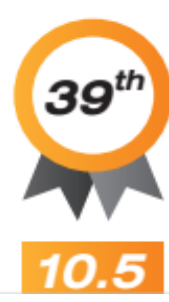

2012

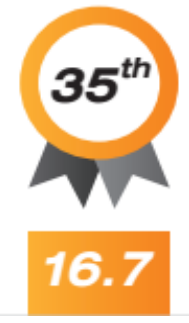

2013

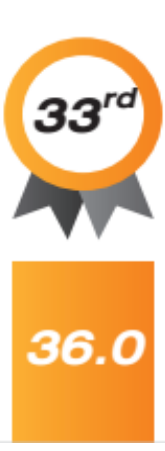

2014

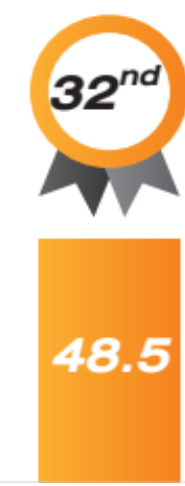

2015

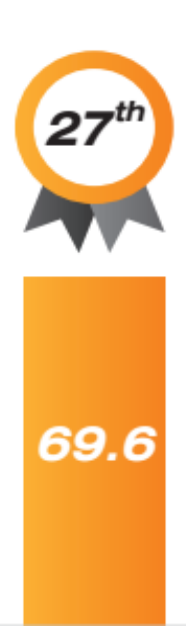

2016

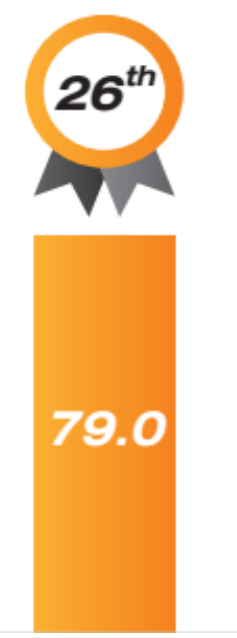

2017 Year

Figure 1. Thailand Futures Exchanges's Rank in World's Leading Derivative Exchanges Source: Thailand Futures Exchange (2018)

In 2017, TFEX reached the average daily volume of 324,217 contracts, a 13.68 percent rise from a year earlier, underpinned by the increasing transactions of stock futures. The investor trading account reached 146,559 accounts, which is 17,275 accounts up from the previous year. The investor breakdown showed local investors accounting for 51.22 percent, local institutions 38.12 percent, while foreign investors representing 10.66 percent. At the end of 2017, the open interest surged to 2,813,036 contracts, an increase of 46.52 percent from the previous year. The key products were stock futures, contributing 40.37 percent, and about 34.69 percent from SET50 index futures and options. As published by the Futures Industry Association (2018), in 2017 SET50 index futures was ranked 42nd among the world's top-50 equity index futures and options contracts.

SET50 futures and options were first listed on TFEX on April 28, 2006 and October 29, 2007, as the first and second products, respectively. Their underlying asset is SET50 index, comprised of the largest 50 listed stocks on the SET index having high market capitalization and high liquidity. The contract multiplier of SET50 index futures was THB 1,000 per index point. SET50 index futures was the most actively traded equity futures contract, before the introduction of stock futures in late 2008. Stock futures slowly gained popularity and finally the trading volume surpassed that of SET50 index futures in 2013. In addition, SET50 index options faced the liquidity problem. Its share in the total trading volume in TFEX was less than 3 percent. TFEX therefore launched the new versions of SET50 index futures and options on October 29, 2012 to provide more investment choices for investors and boost market liquidity. Under the new version of SET50 index futures, there are six contract months, which are three nearest consecutive monthly contracts, and next three quarterly contracts, available for trading each day. For SET50 index options, there are four contract months, which are three nearest consecutive monthly contracts, and another one quarterly contract. Moreover, the strike price interval was widened from 10 points to 25 points, resulting in a significant decrease in the number of series per day. The contract multiplier of SET50 index futures was also reduced to THB 200 per index point on May 6, 2014. Since then SET50 index futures has become the same contract size as SET50 index options. However, Jongadsayakul (2015) shows the results of multiple linear regressions indicating a negative impact of contract modification on option liquidity in terms of both 
trading volume and trading value due to a decrease in investment choices as a reduction in the number of strike prices and a loss of long-term investors as a removal of the two farthest quarterly months.

Both SET50 futures and options are great tools which investors can use to manage their portfolio effectively in case of unanticipated events. Hedgers reduce their risk by taking an offsetting position in a derivative in order to balance any gains and losses to the underlying assets. The main purpose of speculation, on the other hand, is to profit from betting on the direction in which an underlying asset will be moving. Speculators add liquidity to the SET50 index futures and options markets by providing buyers and sellers with partners for their desired trades. While there are advantages to trade SET50 index futures and options contracts for investors, this paper is the first empirical study to determine the factors affecting investor behavior by using the SET50 index futures (options) volumes divided by open interest as a proxy for the relative importance of speculative demand. There is a convention that the daily trading volume primarily proxies movements in speculative activities, whereas the daily open interest variable captures hedging activities in futures and options markets (Rutledge, 1979; Leuthold, 1983; Bessembinder \& Seguin, 1992).

The remainder of this paper is organized as follows: Review of the previous literature is provided in Section II. Section III explains data and methodology while Section IV presents the results followed by a conclusion in Section V.

\section{LITERATURE REVIEW}

The literature supports hedging as the main motive of using derivatives. Some papers mention the speculative reasons behind use of derivatives, but very few researches actually prove or even test this hypothesis (Furqan \& Mirza, 2015). To measure the relative importance of the speculative behavior in derivatives market, many studies combine the volume and open interest data into ratios (García et al., 1986; Gwilym et al., 2002; Lucia \& Pardo, 2010).

Chang et al. (2000) examine the relation between stock market volatility and the demand for hedging in S\&P 500 stock index futures contracts by using open interest as a proxy for hedging demand. The regression results using the extreme-value and GARCH estimates of volatility indicate that daily open interest for hedgers increases when unexpected volatility increases. The increase in the participation of hedgers in periods of higher volatility is significantly larger than the increase in the participation of speculators.

Hagelin (2000) investigates the relationship between options market activity, defined as trading volume divided by open interest, and cash market volatility on the OMX index via Granger causality tests and a regression model. The results show that for the complete sample period there is a unidirectional causality from cash market volatility to options market activity for calls and puts jointly, as well as for calls and puts respectively. While unidirectional causality from cash market volatility to call option trading activity is documented for both subperiods, bilateral causality between put option trading activity and cash market volatility was found for one of the subperiods.

Watanabe (2001) examines the relation between price volatility, trading volume, and open interest for the Nikkei 225 stock index futures traded on the Osaka Securities Exchange. Results for the period prior to February 14, 1994, when the regulation increased gradually, show no relation between price volatility, volume, and open interest. In contrast, results for the period beginning on February 14, 1994, when the regulation decreased gradually, provide a significant positive relation between volatility and unexpected volume and a significant negative relation between volatility and expected open interest. This findings suggest that the relation between price volatility, volume, and open interest may vary with the regulation.

The Korean Stock Exchange's KOSPI 200 index futures and options have been the fastest growing derivatives contracts in the world in recent years. Ciner et al. (2006) identify the factors contributing to the 
success, as measured by trading volume of this market. Empirical results based on a GMM model suggest that trading volume is unlikely to be driven by hedging demand. There are also other researches dealing with the trading activities of the KOSPI 200 derivatives contracts. The dynamic relationship between the KOSPI 200 volatility and futures (options) trading activity is investigated with the simultaneous equation model by Kim et al. (2004). The results show that the derivatives volume, which mainly reflects speculative trading activities, tends to increase the underlying stock market volatility while the open interest, which mainly reflects hedging activities, tends to stabilize the cash market. Chen \& Tang (2009) investigate three major participants, individuals, securities companies, and foreigners, during South Korea's political election periods via a simultaneous equation model. The results show that most of investors trade futures and options contracts to speculate during the complete sample period. By focusing on the three political election periods, investors prefer to hedge using options rather than futures during the latest presidential and parliamentary elections. The results by Lee (2013) show that the trading volumes of KOSPI 200 futures and options and the stock market trading volume have a positive relationship with each other. When the underlying stock market is volatile, it has a positive impact on both futures and options trading volumes.

\section{DATA AND METHODOLOGY}

\subsection{Data}

Utilizing daily data from May 6, 2014 to December 29, 2017, a total of 894 observations, the analysis includes determinants of investor behavior in SET50 index futures and options markets by employing simultaneous equation estimation. The daily data are collected for a period starting May 6, 2014 due to change of the size of SET50 index futures from the multiplier of THB 1,000 to THB 200 per index point, the same contract size as SET50 index options. Following García et al. (1986), the study measures the relative importance of the speculative activity in SET50 index futures (options) by dividing SET50 index futures (options) trading volume by the amount of SET50 index futures (options) open interest. As a proxy of the daily stock market volatility, the relative difference between high and low prices of SET index is employed. Previous papers by Hagelin (2000) and Chen \& Tang (2009) also use the estimator for market volatility based on high and low prices due to its higher information content than an estimator constructed only on closing prices (Garman \& Klass, 1980). A set of explanatory variables include turnover ratio as a measure of stock market liquidity, put-call ratio of SET50 index options, and trading proportion by investor group in each market. All variables used in this paper are listed in Table 1.

Table 1

List of Variables

\begin{tabular}{|l|l|}
\hline \multicolumn{1}{|c|}{ Variables } & \multicolumn{1}{c|}{ Explanations } \\
\hline $\begin{array}{l}\text { The relative importance of the speculative activity in } \\
\text { SET50 index futures market (F) }\end{array}$ & $\begin{array}{l}\text { Trading volume of SET50 index futures divided by the } \\
\text { amount of open interest }\end{array}$ \\
\hline $\begin{array}{l}\text { The relative importance of the speculative activity in } \\
\text { SET50 index options market (O) }\end{array}$ & $\begin{array}{l}\text { Trading volume of SET50 index options divided by the } \\
\text { amount of open interest }\end{array}$ \\
\hline Stock market volatility (S) & $\begin{array}{l}\text { The difference between high and low prices of SET } \\
\text { index divided by low price of SET index }\end{array}$ \\
\hline Turnover ratio (T) & $\begin{array}{l}\text { Ratio of trading volume of SET to the number of } \\
\text { shares outstanding }\end{array}$ \\
\hline Put-call ratio of SET50 index options (PC) & $\begin{array}{l}\text { Ratio of trading volume of SET50 index put options to } \\
\text { SET50 index call options }\end{array}$ \\
\hline $\begin{array}{l}\text { Proportion of foreign investors in SET50 index futures } \\
\text { market (FF) }\end{array}$ & $\begin{array}{l}\text { Trading volume of SET50 index futures by foreign } \\
\text { investors divided by total trading volume }\end{array}$ \\
\hline
\end{tabular}




\begin{tabular}{|l|l|}
\hline $\begin{array}{l}\text { Proportion of local institutions in SET50 index futures } \\
\text { market (IF) }\end{array}$ & $\begin{array}{l}\text { Trading volume of SET50 index futures by local } \\
\text { institutions divided by total trading volume }\end{array}$ \\
\hline $\begin{array}{l}\text { Proportion of foreign investors in SET50 index options } \\
\text { market (FO) }\end{array}$ & $\begin{array}{l}\text { Trading volume of SET50 index options by foreign } \\
\text { investors divided by total trading volume }\end{array}$ \\
\hline $\begin{array}{l}\text { Proportion of local institutions in SET50 index options } \\
\text { market (IO) }\end{array}$ & $\begin{array}{l}\text { Trading volume of SET50 index options by local } \\
\text { institutions divided by total trading volume }\end{array}$ \\
\hline Proportion of foreign investors in stock market (FS) & $\begin{array}{l}\text { Trading value of SET by foreign investors divided by } \\
\text { total trading value (long position only) }\end{array}$ \\
\hline Proportion of local institutions in stock market (IS) & $\begin{array}{l}\text { Trading value of SET by local institutions divided by } \\
\text { total trading value (long position only) }\end{array}$ \\
\hline Proportion of proprietary trading in stock market (PS) & $\begin{array}{l}\text { Trading value of SET by proprietary trading divided by } \\
\text { total trading value (long position only) }\end{array}$ \\
\hline
\end{tabular}

Note: Proportion of local investors in each market is excluded to avoid the multicollinearity problem.

\subsection{Methodology}

The dynamic relationships between the relative importance of the speculative activity in SET50 index futures, the relative importance of the speculative activity in SET50 index options, and stock market volatility are emphasized in equations $1-3$ and investigated with two types of simultaneous equation estimation: (1) single equation method with Two Stage Least Squares (2SLS) estimator and (2) system method with Three Stage Least Squares (3SLS) estimator.

$$
\begin{aligned}
& F=a_{1}+a_{2} \mathrm{O}+a_{3} S+a_{4} \mathrm{~T}+\mathrm{a}_{5} \mathrm{FF}+\mathrm{a}_{6} \mathrm{IF}+\mathrm{e}_{1} \\
& \mathrm{O}=\mathrm{a}_{7}+\mathrm{a}_{8} \mathrm{~F}+\mathrm{a}_{9} \mathrm{~S}+\mathrm{a}_{10} \mathrm{~T}+\mathrm{a}_{11} \mathrm{FO}+\mathrm{a}_{12} \mathrm{IO}+\mathrm{a}_{13} \mathrm{PC}+\mathrm{e}_{2} \\
& \mathrm{~S}=\mathrm{a}_{14}+\mathrm{a}_{15} \mathrm{~F}+\mathrm{a}_{16} \mathrm{O}+\mathrm{a}_{17} \mathrm{~T}+\mathrm{a}_{18} \mathrm{FS}+\mathrm{a}_{19} \mathrm{IS}+\mathrm{a}_{20} \mathrm{PS}+\mathrm{e}_{3}
\end{aligned}
$$

The analysis uses simultaneous equation estimation since $\mathrm{F}, \mathrm{O}$, and $\mathrm{S}$ are said to be endogenous variables. Chen \& Tang (2009) also suggest the simultaneous equation model to investigate the dynamic relationships between cash market volatility and derivatives trading activities. It can be confirmed by conducting test of exogeneity, the Hausman test. This is a test of whether one or more right-hand side variables are exogenous against the alternative they are endogenous. A p-value of 0.0000 from the Hausman test indicates the existence of endogeneity. When an explanatory variable is correlated with the error term, the ordinary least squares estimator is biased and inconsistent. On the other hand, the 2SLS estimator is consistent regardless of whether or not the error term is correlated with an explanatory variable. Moreover, the 3SLS method generalizes the 2SLS method to take account for possible contemporaneous correlation of error terms. If there is no heteroscedasticity, then 3SLS estimator is both consistent and asymptotically more efficient than 2SLS estimator.

\section{EMPIRICAL RESULTS AND DISCUSSION}

Table 2 presents descriptive statistics, namely mean, standard deviation, minimum, and maximum, of all variables used in this paper. The average value of variable for measuring the relative importance of the speculative activity in SET50 index futures market $(F)$ is 0.3738 , which is higher than the average value of variable $\mathrm{O}$ as a measure of the relative importance of the speculative activity in SET50 index options market. This result suggests that speculative profit-oriented trading rather than hedging profit-oriented trading is more likely to be happened in SET50 index futures market than in SET50 index options market. It can be seen that the average daily stock market volatility of the SET index is 0.88 percent. The minimum and maximum values of stock market volatility are 0.26 percent and 8.58 percent respectively. The average turnover ratio is 0.5434. Local investors are the main investors in both stock and derivatives markets as evidenced by their trading activities which account for more than 50 percent. On average, proportions of 
foreign investors and local institutions in SET50 index futures (options) market are 19.83 (5.33) percent and 22.64 (25.07) percent respectively. According to investor breakdown by trading value of SET, foreign investors account for 25.72 percent, local institutions at 10.72 percent, while proprietary trading at 10.37 percent. In SET50 index options market, the average put-call ratio is 1.3371 , which suggests traders are buying more puts than calls. The Augmented Dickey Fuller (ADF) test is also conducted to evaluate whether the time series are stationary or not. Table 2 shows that all time series are stationary at the 1 percent level of significance.

Table 2

Descriptive Statistics of Variables

\begin{tabular}{|c|c|c|c|c|c|c|c|}
\hline \multirow{2}{*}{ Variables } & \multirow{2}{*}{ Mean } & \multirow{2}{*}{ Std. dev. } & \multirow{2}{*}{ Minimum } & \multirow{2}{*}{ Maximum } & \multicolumn{3}{|c|}{ ADF } \\
\cline { 6 - 8 } & & & & & Model & Lags & Test value \\
\hline F & 0.3738 & 0.1577 & 0.1102 & 1.7197 & w trend & 0 & -13.5699 \\
\hline O & 0.0821 & 0.0551 & 0.0115 & 0.4510 & w/o trend & 2 & -11.1893 \\
\hline S & 0.0088 & 0.0054 & 0.0026 & 0.0858 & w trend & 1 & -13.9224 \\
\hline T & 0.5434 & 0.2972 & 0.2100 & 2.6300 & w trend & 2 & -8.2736 \\
\hline FF & 0.1983 & 0.0987 & 0.0795 & 0.7820 & w trend & 0 & -12.4526 \\
\hline IF & 0.2264 & 0.0488 & 0.0606 & 0.3830 & w trend & 1 & -11.1408 \\
\hline FO & 0.0533 & 0.0674 & 0.0000 & 0.3662 & w/o trend & 2 & -10.1118 \\
\hline IO & 0.2507 & 0.1032 & 0.0000 & 0.5898 & w/o trend & 6 & -4.4304 \\
\hline PC & 1.3371 & 0.9031 & 0.1827 & 14.0962 & w/o trend & 6 & -8.5214 \\
\hline FS & 0.2572 & 0.0668 & 0.0661 & 0.6246 & w trend & 2 & -11.1988 \\
\hline IS & 0.1072 & 0.0321 & 0.0357 & 0.3838 & w trend & 3 & -10.2635 \\
\hline PS & 0.1037 & 0.0187 & 0.0416 & 0.1943 & w trend & 3 & -9.4260 \\
\hline
\end{tabular}

Note: At the significance level of 0.01, critical values for the ADF test with (w) and without (w/o) trend are -4.011 and -3.481 respectively. The selection of the lag length is based on Schwarz information criterion.

Since the p-value of the Hausman test is 0.0000 , indicating the existence of endogeneity, two types of simultaneous equation estimation are conducted to examine the determinants of investor behavior in SET50 index futures and options markets. Table 3 reports the 2SLS and 3SLS estimations of the regression coefficient with t-statistic value in parenthesis.

Table 3 shows that the 2SLS and 3SLS methods produce the same estimations in terms of the significant variables. Most of t-statistic values generated by 3SLS are higher than 2SLS. Both 2SLS and 3SLS estimators show the positive impact of stock market volatility on the relative importance of the speculative activities in SET50 index futures and options markets at the 1 percent level of significance. When the stock market generates price volatilities, investors increase their relative speculative demand for SET50 index futures rather than SET50 index options as evidenced by the estimated coefficient of stock market volatility in equation 1 higher than that of equation 2. Both models also show that bilateral causality within stock market volatility and the relative importance of the speculative activity in SET50 index futures or options exists at the 1 percent level of significance. This suggests that greater speculative demand relative to hedging demand for SET50 index futures or options corresponds to greater stock market volatility. Between SET50 index futures and options markets, there is a negative relationship. 3SLS method shows bilateral causality at the 1 percent level of significance, but 2SLS method provides unidirectional causality from SET50 index futures activity to SET50 index options activity at the 10 percent level. Interestingly, the signs of the turnover ratio coefficients are mixed among three equations. At the 1 percent level of significance, both 2SLS and 3SLS methods show a positive impact of turnover ratio on stock market volatility but a negative impact of 
turnover ratio on the relative importance of the speculative activity in SET50 index futures. Only 3SLS estimator provides a significantly negative coefficient of turnover ratio in options market at the 5 percent level. An increase in turnover ratio leads to higher volatility in SET index but lower relative speculative activities in both SET50 index futures and options markets.

Table 3

Results from the Simultaneous Equation Estimation

\begin{tabular}{|c|c|c|c|c|c|c|}
\hline & \multicolumn{3}{|c|}{ 2SLS estimator } & \multicolumn{3}{|c|}{ 3SLS estimator } \\
\hline & Equation 1 & Equation 2 & Equation 3 & Equation 1 & Equation 2 & Equation 3 \\
\hline & $\mathrm{F}$ & $\mathrm{O}$ & $\mathrm{S}$ & $F$ & $\mathrm{O}$ & $\mathrm{S}$ \\
\hline \multirow{2}{*}{ Constant } & 0.002670 & 0.009139 & $0.003238^{* * *}$ & 0.015996 & 0.015116 & $-0.002618^{* * *}$ \\
\hline & $(0.058559)$ & $(0.938119)$ & $(2.656314)$ & $(0.429075)$ & $(1.582544)$ & $(-3.370739)$ \\
\hline \multirow[t]{2}{*}{ F } & & $-0.061269^{*}$ & $0.009294^{* * *}$ & & $-0.140575^{* * *}$ & $0.010626^{* * *}$ \\
\hline & & $(-1.936156)$ & $(3.711888)$ & & $(-4.823236)$ & $(5.015194)$ \\
\hline \multirow[t]{2}{*}{$\mathbf{O}$} & -0.268456 & & $0.046139^{* * *}$ & $-1.492071^{* * *}$ & & $0.045639^{* * *}$ \\
\hline & $(-0.717784)$ & & (5.779388) & $(-4.736047)$ & & (6.214528) \\
\hline \multirow[t]{2}{*}{$\mathrm{S}$} & $46.44992^{* * *}$ & $6.486383^{* * *}$ & & $57.48178^{* * *}$ & $11.98524^{* * *}$ & \\
\hline & $(9.113406)$ & $(5.01607)$ & & $(13.82377)$ & $(11.23709)$ & \\
\hline \multirow[t]{2}{*}{$\mathbf{T}$} & $-0.094533^{* * *}$ & 0.007202 & $0.002072^{* * *}$ & $-0.137594^{* * *}$ & $-0.016048^{* *}$ & $0.003256^{* * *}$ \\
\hline & $(-4.009722)$ & $(0.834311)$ & $(3.126124)$ & $(-6.113942)$ & $(-2.072989)$ & $(5.760319)$ \\
\hline \multirow[t]{2}{*}{ FF } & $0.549804^{* * *}$ & & & $0.363611^{* * *}$ & & \\
\hline & $(8.433447)$ & & & (6.887716) & & \\
\hline \multirow[t]{2}{*}{ IF } & $-0.324340^{*}$ & & & -0.102213 & & \\
\hline & $(-1.925506)$ & & & $(-0.956188)$ & & \\
\hline \multirow[t]{2}{*}{ FO } & & $0.137199^{* * *}$ & & & $0.068532^{* * *}$ & \\
\hline & & (5.155713) & & & (3.372661) & \\
\hline \multirow[t]{2}{*}{ IO } & & $0.084386^{* * *}$ & & & $0.057026^{* * *}$ & \\
\hline & & $(4.216427)$ & & & $(3.418152)$ & \\
\hline \multirow[t]{2}{*}{ PC } & & $0.004748^{* *}$ & & & $0.003556^{* * *}$ & \\
\hline & & $(2.433861)$ & & & $(2.583973)$ & \\
\hline \multirow[t]{2}{*}{ FS } & & & $-0.008240^{* * *}$ & & & 0.000645 \\
\hline & & & $(-3.697729)$ & & & $(0.636835)$ \\
\hline \multirow[t]{2}{*}{ IS } & & & $-0.012796^{* * *}$ & & & 0.003079 \\
\hline & & & $(-2.847128)$ & & & $(1.503642)$ \\
\hline \multirow[t]{2}{*}{ PS } & & & 0.006477 & & & $0.013881^{* * *}$ \\
\hline & & & $(0.631531)$ & & & $(2.590802)$ \\
\hline
\end{tabular}

Note: $*$ indicates significance level at 0.10 level, ** indicates significance level at 0.05 level, *** indicates significance level at 0.01 level.

Focusing on trading proportion by investor group, the coefficient of proportion of foreign investors in SET50 index futures market is found to be positive and significant at the 1 percent level in both 2SLS and 3SLS methods. When foreign investors increase their trading proportion, they proceed to trading SET50 index futures contracts for speculation rather than hedging. Both coefficients of proportions of foreign investors and local institutions in SET50 index options market are significantly positive at the 1 percent level. An increase in trading proportion by either foreign investors or local institutions precedes greater speculative demand rather than hedging demand in SET50 index options market. Interestingly, all the 
regressions have significant and positive coefficient of put-call ratio at least 5 percent level. This implies that speculative trading is mostly related to put options, while hedging trading is mostly related to call options. In case of trading proportions of foreign investors and local institutions in stock market, their coefficients are significantly negative only in 2SLS model at the 1 percent level. On the other hand, the result of 3SLS method only shows a significantly positive impact of proprietary trading proportion on stock market volatility at the 1 percent level.

\section{CONCLUSION}

This study aims to examine the determinants of investor behavior, speculative demand relative to hedging demand, in SET50 index futures and options markets by using 2 types of simultaneous equation estimation: (1) single equation method with Two Stage Least Squares (2SLS) estimator and (2) system method with Three Stage Least Squares (3SLS) estimator. The regression analysis uses daily data from May 6, 2014 to December 29, 2017 due to change of the contract size of SET50 index futures to be the same size as SET50 index options on May 6, 2014. To measure the relative importance of the speculative activity in SET50 index futures (options) market, SET50 index futures (options) trading volume is divided by the amount of open interest. The relative difference between high and low prices of SET index is also employed as a proxy of the daily stock market volatility.

The findings from both 2SLS and 3SLS methods show bilateral causality between stock market volatility and derivatives market activities. Between SET50 index futures and SET50 index options markets, the 3SLS model implies that these two markets have leading behaviors with one another, but there is a unidirectional causality from futures trading activity to options trading activity in 2SLS model. Both 2SLS and 3SLS methods show a positive impact of turnover ratio on stock market volatility but a negative impact of turnover ratio on the relative importance of the speculative activity in SET50 index futures. Only 3SLS estimator provides a significantly negative coefficient of turnover ratio in options market. Moreover, only proportion of foreign investors shows a positive relationship with speculative investor behavior in SET50 index futures market. An increase in trading proportion by either foreign investors or local institutions precedes greater speculative demand rather than hedging demand in SET50 index options market. Speculative trading is mostly related to SET50 index put options, while hedging trading is mostly related to SET50 index call options. The coefficients of trading proportion by investor group in stock market, on the other hand, are mixed.

Since speculators add liquidity to the derivatives market, the findings of this study suggest that Thailand Futures Exchange should support more investment from foreign investors in SET50 index futures market and from both foreign and institutional investors in SET50 index options market. Due to bilateral causality between stock market volatility and derivatives trading activities, increases in stock market volatility increase the demand for speculation in derivatives market, and futures and options trading may destabilize the underlying market.

\section{ACKNOWLEDGEMENT}

The author is thankful to Department of Economics, Faculty of Economics, Kasetsart University for financial support to carry out this research. 


\section{REFERENCES}

Bessembinder, H., \& Seguin, P. J. (1992). Futures Trading Activity and Stock Price Volatility. Journal of Finance, 47(5), 2015-2034. https://doi.org/10.1111/j.1540-6261.1992.tb04695.x

Chang, E., Chou, R. Y., \& Nelling, E. F. (2000). Market Volatility and the Demand for Hedging in Stock Index Futures. Journal of Futures Markets, 20(2), 105-125. https://doi.org/10.1002/(SICI)1096-9934(200002)20:2<105::AIDFUT1>3.0.CO;2-Q

Chen, C., \& Tang, W. (2009). Are They Hedgers or Speculators? Evidence from South Korea's Political Elections. Emerging Markets Finance \& Trade, 45(1), 19-30. https:/ / doi.org/10.2753/REE1540-496X450102

Ciner, C., Karagozoglu, A. K., \& Kim, W. S. (2006). What is so Special about KOSPI 200 Index Futures Contract? Analysis of Trading Volume and Liquidity. Review of Futures Markets, 14(3), 327-348.

Furqan, M., \& Mirza, N. (2015). Motives Behind the Use of Derivatives: Hedging or Speculation?. Pakistan Business Review, 17(2), 450-461. Retrieved from https://www.journals.iobmresearch.com/index.php/PBR/article/ view/126/55

Futures Industry Association. (2018). Total 2017 volume 25.2 billion contracts, down $0.1 \%$ from 2016. Retrieved from https:// fia.org/node/3318/?utm_source=FIAHP\&utm_medium=carousel\&utm_campaign =Vol2017

García, P., Leuthold, R. M., \& Zapata, H. (1986). Lead-lag Relationships between Trading Volume and Price Variability: New Evidence. Journal of Futures Markets, 6(1), 1-10. https://doi.org/10.1002/fut.3990060102

Garman, M. B., \& Klass, M. J. (1980). On the Estimation of Security Price Volatilities from Historical Data. Journal of Business, 53(1), 67-78. https://dx.doi.org/10.1086/296072

Gwilym, O. A., Buckle, M. J., \& Evans, P. (2002). The Volume-maturity Relationship for Stock Index, Interest Rate and Bond Futures Contracts. EBMS Working Paper. European Business Management School, University of Wales, Swansea.

Hagelin, N. (2000). Index Option Market Activity and Cash Market Volatility under Different Market Conditions: an Empirical Study from Sweden. Applied Financial Economics, 10(6), 597-613. https://doi.org/10.1080/096031000437953

Jongadsayakul, W. (2015). The Study of the Liquidity of SET50 Index Options. Proceedings of 53th Kasetsart University Annual Conference. Kasetsart University, Bangkok, 413-421. Retrieved from http://annualconference.ku.ac.th/cd53/12_002_O5.pdf

Kim, M., Kim G. R., \& Kim, M. (2004). Stock Market Volatility and Trading Activities in the KOSPI 200 Derivatives Markets. Applied Economics Letters, 11(1), 49-53. https://doi.org/10.1080/1350485042000187462

Lee, H. S. (2013). Determinants of the KOSPI 200 Futures and Options Markets Trading Volume. Capital Market Perspective, 5(1), 29-44. Retrieved from https://www.kcmi.re.kr/common/downloadw.asp?fid=16646\&fgu $=002001 \& \mathrm{fty}=004003$

Leuthold, R.M. (1983). Commercial Use and Speculative Measures of the Livestock Commodity Futures Markets. Journal of Futures Markets, 3(2), 113-135. https:/ / doi.org/10.1002/ fut.3990030202

Lucia, J. J., \& Pardo, A. (2010). On Measuring Speculative and Hedging Activities in Futures Markets from Volume and Open Interest Data. Applied Economic, 42(12), 1549-1557. https://doi.org/10.1080/00036840701721489

Rutledge, D. J. S. (1979). Trading Volume and Price Variability: New Evidence on the Price Effects of Speculation. International Futures Trading Seminar Proceedings Volume V. Chicago Board of Trade, Chicago, 160-186.

Thailand Futures Exchange. (2018). 12th Anniversary Futures Exchange. Retrieved from https://www.tfex.co.th/th/education/files/TFEX_12yrs_Booklet.pdf

Watanabe, T. (2001). Price Volatility, Trading Volume, and Market Depth: Evidence from the Japanese Stock Index Futures Market. Applied Financial Economics, 11(6), 651-658. https://doi.org/10.1080/096031001753266939 